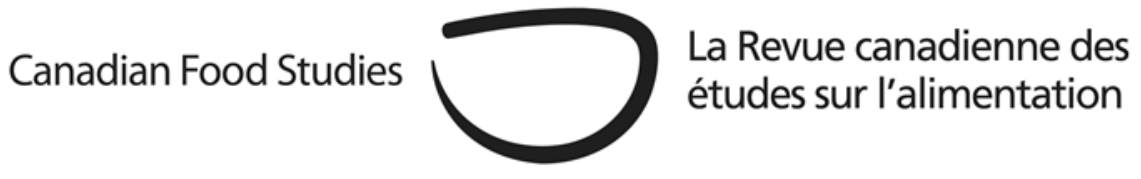

Original Research Article

\title{
Digging through urban agriculture with feminist theoretical implements
}

\author{
Mary Anne Martin*
}

Trent University

\begin{abstract}
This article considers the value of using tools from feminist theory to explore the efforts of urban agriculture initiatives that practice to some extent outside the formal economy. Such a lens looks beyond the presence of women in specific projects to the value, extent, purpose, and principles of these projects' efforts. These community-based food initiatives strive to provide alternatives to dominant food production practices, but their efforts are often constrained by limited access to financial, labour, time, and political resources. Despite parallels between their work and what has traditionally been dubbed "women's work," the feminization of urban agriculture initiatives in Canada has received little attention in the academic literature. In this article, I consider Durham Integrated Growers (DIG), an umbrella organization supporting urban agriculture projects, practices, and values across Durham Region, Ontario. DIG is one organization studied by Nourishing Communities Research Group's Social Economy of Food project, which explored the potential of food systems groups working in the social economy to benefit local communities and the environment. This earlier research on DIG revealed themes involving the need for community expertise to be recognized, the role of public policy, the effects of relying on unpaid labour, and the centrality of building community. By using feminist framings to reconsider the ways DIG approaches identity, knowledge, work, and relationship, I find many areas where the organization's work could be better understood. Although more study is required on a broader range of urban agriculture initiatives, this research suggests that feminist theoretical tools such as intersectionality, social reproduction, and ethics of care may provide useful resources for illuminating and revaluating their practical, educational, and relational impacts.
\end{abstract}

*Corresponding author: marymartin2@trentu.ca

DOI: $10.15353 /$ cfs-rcea.v6i3.356 
Keywords: urban agriculture; social economy; feminist theory; community food initiatives

Introduction

From 2015 to 2016, I investigated Durham Integrated Growers for a Sustainable Community (DIG) as one of several case studies in the Social Economy of Food project undertaken by the Nourishing Communities Sustainable Local Food Systems Research Group (Nourishing). ${ }^{1}$ DIG focuses on promoting healthier, more sustainable communities through its support of urban agriculture or "the growing of plants and the raising of animals within and around cities" (RUAF Foundation, 2019) for the purpose of food. Nourishing researchers worked with a range of food initiatives that operate in the social economy and involve informal economic activities. That is, these initiatives' goals extend beyond economic ones to include social and environmental ones and their economic activities include under-recognized ones, such as forms of bartering, unpaid labour, and self-provisioning. The case studies explored the ways in which these social economy initiatives contribute to marginalized groups and the environment, with specific regard to fostering community resilience, social capital, prosperity, innovation, and connections across difference. This Nourishing research has brought more attention to and met some of the needs of food initiatives in the social economy through the development of case study reports, participatory action research projects, webinars, articles, videos, a visioning workshop, related follow-up report, and conference panel.

Up to now, however, this collection of work within the project subtitled "Informal, underrecognized contributions to community prosperity and resilience" (Nourishing Communities, n.d.) has largely neglected gender dynamics and the broad feminist literature regarding informal work and its impacts. I contend that using feminist theoretical tools to study urban agriculture initiatives like DIG may deepen an understanding of them and how they interact with actors in their "ecosystems" such as government and funding institutions. In the following pages I consider the applicability of such tools to DIG, more as a cohesive, multi-layered organization and less as a collection of gendered individuals. One reason for this reading is to respond to a shortage of scholarly material on the feminization of urban agriculture organizations, especially in Canada and North America. Moreover, I wanted to investigate what I suspect is an implicit, under-articulated feminine coding of urban agriculture that may contribute to these forms of food production being undervalued, underfunded, and marginalized. A feminist, organization-focused reading of DIG considers the "what" of feminization to be at least as important as the "who". Vosko (2000) illustrates that feminization pertains to more than the presence of women when she

\footnotetext{
${ }^{1}$ The case study reports are available at: http://nourishingontario.ca/the-social-economy-of-food/casestudies-subversions-from-the-informal-and-social-economy/
} 
describes the feminization of paid work as requiring consideration of men's increasing position in it. Swanson (2015) has also given much thought to exploring the feminine without essentializing people, dualizing genders, or dividing groups. She determines that, "it is practical to acknowledge and celebrate the feminine both in traditional meanings and through a contemporary understanding of feminine as characteristics that are not the sole domain of women" (Swanson, 2015, p. 99). Here I use the term feminization in two overlapping ways, to refer to: 1) an association with traits that have been broadly seen as feminine or attributed to women, and 2) social positioning that traditionally or enduringly affects women disproportionately.

This article begins with an overview of DIG and the literature on intersections of foodgrowing and gender. I proceed to introduce my methodology including the theoretical frames I draw on from feminist theory, namely intersectionality, social reproduction, and ethics of care. From there, I consider DIG's approaches to issues of identity, knowledge, work, and relationship in the light of these feminist lenses. Through this article, I seek to demonstrate how considering their application to the study of urban agriculture may constitute a worthwhile project for illuminating and revaluating urban agriculture's social and environmental impacts.

\section{Durham Integrated Growers for a Sustainable Community (D/G)}

DIG works as an umbrella organization supporting urban agriculture projects, practices, values, and policies across Durham Region in southern Ontario, Canada. Its mission states that it "supports local community food production and food security" (DIG, n.d.). DIG's work traverses municipal and urban-rural boundaries, extending to all eight of Durham's local municipalities while also focusing on the region as a whole. This broad geographic scope shapes DIG's view of urban agriculture. Although urban agriculture is often simply equated with the establishment of community gardens in cities, DIG views it as encompassing all parts of the food system (producing, processing, and distributing local food) both in and around cities and towns. Indeed, DIG supports projects like community gardens as well as urban farms, urban orchards, pollinator gardens, and local food entrepreneurs throughout Durham's urban and rural landscape.

DIG's purpose is to contribute to a healthier, more resilient community through a stronger, more sustainable food system. Towards this goal, the organization shares knowledge and skills, offers technical assistance to local urban agriculture projects, helps projects develop partnerships and funding, promotes sustainable practices and the value of local food, conducts research and policy analysis, and advocates with government. Its programs include yearly garden tours, trips designed to educate people about the food system, "Table Talk" community workshops, the "You Grow Durham Fund" for new community projects, and community presentations. Any urban agriculture project in Durham Region can become a member of DIG although member projects operate independently, seeking DIG's assistance as necessary. 
Overall, main themes revealed in the Nourishing DIG case study include: "the [need for] recognition of community expertise, the role of supportive and restrictive municipal policies, the benefits and pitfalls of relying on unpaid labour, [and] a focus on fostering community" (Martin, 2016, p.4). Among social economy organizations, which emphasize human relationships and non-mainstream economic activity (McMurtry, 2004), such themes may be predictable. However, I believe that, in conjunction with other materials about DIG, they also suggest a current flowing through social economy work, particularly urban agriculture, that lends itself to a feminist analysis.

\section{Gender and the who of food production}

While my intent is not to emphasize the ways in which urban agriculture plays out differently along gender lines among individuals, the following short overview of literature on gender in food production provides a backdrop for my analysis. Although some authors have explored the ways in which gender dynamics transpire within urban agriculture projects (e.g. Buckingham, 2005; DeLind \& Ferguson, 1999; Parry, Glover, \& Shinew, 2005), less scholarly material has applied a feminist lens to these initiatives at a project or organizational level.

Agriculture in general continues its longstanding reputation as the domain of men regardless of the roles that women have occupied on the farm and in the farm home (Brandth \& Haugen, 2010; Chiappe \& Butler Flora, 1998; Moyles, 2018). On a global scale, women's farming produces about 40 percent of all food (Sachs \& Patel-Campillo, 2014). Moyles (2018) contends that it feeds most of the world's population and contributes to families, communities, and "the public good" (p. 253) while, like women's work more generally, remaining largely invisible, undervalued, and missing from statistical accounting. In fact, according to Brandth \& Haugen (2010), "conventional rural masculinities are rarely dismantled" (p. 426) and in fact, "no matter what [farm] women do, their discursive placement as the farmer's wife is dominant and overshadows other definitions of woman" (p. 426).

Moyles (2018) provides an example from Canadian history of this gendering of food production: during World War 1l, the federal government encouraged more women into farm work by using the term "farmerettes" (p. XVII) to soften this labour's masculine coding. While their sisters headed to the factories, over a million women moved into the fields. Similarly, in urban areas, women were encouraged to grow victory gardens for their households' sustenance. However, the reluctance to identify women as actual farmers persisted, and their massive contributions, both rural and urban, to the nation's wartime food production remains absent from most historical records (Moyles, 2018).

Today, women worldwide face disproportionate barriers to material and educational agricultural resources (Sachs \& Patel-Campillo, 2014). In Canada, even as women constitute an increasing proportion (28.7 percent) of farm operators (Statistics Canada, 2017), they face 
continued challenges, such as general lack of faith in their abilities and a shortage of family land, equipment, and knowledge handed down to daughters (Moyles, 2018).

From an urban agriculture perspective, the findings of Parry et al. (2005) on gendered divisions of labour in community gardens strongly resemble such divisions found in the domestic realm. That is, domestic labour also relies heavily on women's cognitive work, project oversight, and delegation to men (DeVault, 1991; Fox, 2009; Miller, 2011) and those involved tend to still discount gender as a factor in such divisions (Beagan, Chapman, D’Sylva, \& Bassett, 2008; Brady, Gingras, \& Power, 2012; DeVault, 1991; Tronto, 2013). Brandth et al. (2010) found a similar arrangement of "catering, cleaning and caring" (p. 434) work among heterosexual couples who had transitioned from farm operations to farm tourism businesses. In fact, these couples were encouraged by their guests to demonstrate traditional gender divisions. At the same time, urban agriculture may exhibit more flexibility in gender relations than conventional agriculture does. For instance, community gardens highlight not only traditional gender roles but also the initiation by and leadership of women (Parry et al., 2005; Schmelzkopf, 1995).

\section{Gender and the how of food production}

Who grows food can significantly affect how food production occurs. Exclusion from farming resources and support has led women in Canada to turn to certain practices such as agricultural education, small-scale and less physically demanding farming methods, the support of other aspiring young or female farmers, creative means to secure land and to produce food, and production-centred political change efforts (Moyles, 2018). Small-scale farming tends to be a practice of women, particularly marginalized women, on a global scale as well (Sachs \& PatelCampillo, 2014).

A gendered organization is also revealed in the philosophies underlying production. For instance, Moyles (2018) asserts that, "The efforts of women farmers tend to be localized: feed the family, feed the community, and steward the land" (p. 254). She finds that these women are generally guided by a love of the land, animals, plants, seeds, and agricultural tasks, as well as the desire to create better futures and greater financial security for their families. Chiappe et al. (1998) trace a male tendency to assume control over agricultural resources and a female tendency to focus more on the needs of family and the common good back to women's naturalization as nurturers and men's separate naturalization as strong and rational beings. In particular, these authors notice women farmers prioritizing "quality family life" (p. 387) which focuses on health and time with family, something the women said was facilitated through alternative agricultural methods. These farmers also valued "spirituality/religiousity" (p. 390) and "honouring of nature" (p. 390) shown through incorporating a holistic approach and caring for the earth. 
Within the context of Community Supported Agriculture (CSA), ${ }^{2}$ DeLind and Ferguson (1999) discovered a tendency for men to focus on new friendships, skill development, and selfimprovement while the women in their study centred more on tranquillity, holistic approaches, responsibility to the farm, and opportunities for community-building, especially through social responsibility and democratic approaches. Generally, the women "were less willing to isolate issues, separate functions, and minimize feelings" (p. 196), focusing instead beyond, often broadly beyond, their own needs. This collective and other-focused orientation may constitute not only an alternative approach to food production, but a necessary one. Indeed, through investigating a CSA farm, Sumner, Mair, and Nelson (2010) discovered that culture and the relationships built with the community not only contribute to alternative agriculture initiatives, but also help to sustain those initiatives and their ability to provide people with food. "Culture" here was evidenced through "civic engagement, community and the celebration of local food" (p. 58).

Overall, the literature reveals that women continue to play a substantial role in agriculture but to experience barriers there to access and recognition. The response by many women to these gendered exclusions has been to approach agriculture in more traditionally feminine ways, essentially bringing it closer to the smaller, holistic, and relationship-focused approaches of urban agriculture.

\section{Methodology}

Through this research, I set out to explore the value of feminist lenses for exploring urban agriculture organizations. To do so, I conducted a close review of the Social Economy of Food project's outputs related to DIG. These include a case study, participatory action research project, webinar, and video. I also draw on my own direct participation with DIG as a volunteer board member. I proceed to reconsider DIG as an organization through the lens of feminist theoretical tools that provide ways to elucidate under-represented perspectives. These overlapping tools, described below, include intersectionality, social reproduction, and ethics of care. This process responds in part to calls for greater feminist analysis of foodwork and food activism (Allen \& Sachs, 2007; Brady, Parker, Belyea, \& Power, 2018; Brady et al., 2012).

\footnotetext{
${ }^{2}$ Community Supported Agriculture (CSA) refers to a farm marketing strategy whereby farmers share both the bounty and risks of an upcoming growing season with their customers by selling them produce shares at the beginning of the season. The farmers then distribute their harvests to their customers in the form of weekly or bi-weekly produce boxes during the growing season. Because CSAs may be located in rural or urban settings, and may incorporate both conventional and alternative farming practices, as a category they straddle the boundary between general agriculture and urban agriculture.
} 


\section{Intersectionality}

From a home in feminist theory, the concept of intersectionality has traveled across disciplines and sectors well beyond gender studies and activism. Simply put, an intersectional lens examines the ways in which differences among people and among structures of inequality interconnect and shape individual perspectives and experiences (Hesse-Biber \& Leckenby, 2004; Hill Collins, 2009). According to Cho, Crenshaw and McCall (2013), it is "inextricably linked to an analysis of power" (p. 797). The academic development of intersectionality stems back to the 1980s and the identified need "to focus attention on the vexed dynamics of difference and the solidarities of sameness in the context of antidiscrimination and social movement politics" (Cho et al, 2013, p. 787). Early understandings of intersectionality were more mechanistic, focusing primarily on intersecting factors in isolation. In time, these "additive" (Yuval-Davis, 2006, p.173) approaches were largely dismissed in favour of more "mutually constitutive" (p.173) approaches that explore the specific ways in which forms of difference and structures of inequality influence each other. For instance, Hill Collins (2009) uses the term "matrix of domination" (p. 18) to conceptualize the ways that power is used to organize multiple systems of inequality and their varying significance depending on situation, time, and place. Critiques of intersectionality concern an overemphasis on identity and related de-politicization (Collins \& Bilge, 2016) and a neglect of both transnational interrelatedness and interscalar connections such as those between local and global scales (Patil, 2013).

\section{Social reproduction}

Social reproduction constitutes another way that feminist scholars, especially feminist political economists, conceive of power relations and make visible underrepresented experiences and perspectives. According to Bezanson (2006), social reproduction "encompasses the work that must be done in order to ensure that people at least survive and ideally thrive and develop, as well as to ensure that the economic system is perpetuated" (p. 26). This form of labour goes largely unrecognized in both social policy (McKeen, 2004) and capitalist systems (Acker, 2006), although it is foundational to the functioning of both. Instead, it often remains unpaid or underpaid, women-performed, and devalued (Bezanson, 2006; Luxton, 2006). Although a central struggle has regarded how to reconcile the materiality, political analysis, and market focus of a social reproductive lens with the affective nature of the caring work involved (Dowling, 2016; Duffy, 2011), conceptions of social reproduction have over time expanded to include cognitive and emotional labour, along with practical labour (Luxton, 2006). 


\section{Ethics of care}

If a social reproduction lens concerns itself with the bread of materiality, an ethics of care approach addresses the just-as-essential roses of connection. Although both perspectives are concerned with caring labour, social reproduction focuses more on the labour itself and its positioning and function within economic and political structures, while an ethics of care considers the interrelatedness of and interdependencies within broadly defined communities (Neysmith, Reitsma-Street, Baker-Collins, \& Porter, 2012). For instance, Tronto's (2013) "feminist democratic ethics of care" (p. 29) views people not only as existing within relationships, but also as all providing and receiving care in their lifetimes. Swanson's (2015) "ecofeminist ethics of care" (p. 96) expands the circle to reveal the interdependence of all life on Earth. Although adversarial and economy-preoccupied political climates leave little space for discussions of care, essentially relocating it even further from what Smith (1999) refers to as the "main business" (p. 37) of capitalism, a focus on care is necessary in all forms of leadership (Swanson, 2015; Tronto, 2013). Tronto (2013) cautions against conceptualizing care as the natural purview of women, based in women's love, commodifiable, or beyond the scope of politics. Instead, she contends that determining how to care for society's members is crucial for solving obdurate global problems like terrorism. Swanson (2015) likewise contends that, "Only in caring is there hope for humanity, and a healthy future on this planet" (p.101).

Results: Uses of feminist theoretical tools

A close review of DIG materials revealed four terrains on which the organization is feminized. These include identity, knowledge, work, and relationship. Here I consider each of them, how they function through DIG, and what feminist lenses may reveal about them.

\section{Identity}

Before considering DIG specifically in this section, I look at the relationship between rural and urban food growing. Even if sites of urban food production carry a sense of novelty today, foodgrowing in cities is far from new. Despite this, the position of the term urban agriculture at the intersection of what is conceived to be urban and what is conceived to be agricultural continues to constitute a conceptual dissonance, an unimaginable entity. However, an intersectional analysis may provoke questions about what it means to both produce food and exist in urban spaces. The popular Grain Farmers Ontario-initiated campaign "Farmers Feed Cities" which ran for about a decade until 2014 provides a useful illustration (Brodhagen, 2014). The campaign title highlights a crucial relationship between rural agriculture and urban eaters, but it also serves to keep them conceptually separate by distinguishing food producers from city dwellers, many of 
whom feed cities in diverse ways. However, an intersectional lens can consider food growing along multiple axes of power. It can challenge assumptions of rurality in food-growing by reconsidering, not only the location of food production, but also entrenched assumptions of White, settler, masculinized, and for-profit profiles of food-growing associated with the concept of "farmer."

Despite its city-associated nomenclature, urban agriculture is regarded by DIG as "the growing, raising, processing and distribution of food and food-related products within towns, cities and urban centres (intra-urban) or around them (peri-urban) in an environmentally responsible manner" (Martin, 2016, p.1). One of DIG's goals has been to encourage its local municipal governments to adopt such a definition that similarly extends beyond strictly urban sites and into more rural areas. Indeed, one successful small-town Durham community garden borders both an elementary school and many acres of farmers' fields. DIG's goal is not to resituate conventional agriculture into rural spaces but to show how the practices of and lessons learned from urban agriculture are replicated across communities of all sizes.

Beyond overlooking the occurrence of urban agriculture in rural spaces, some municipal leaders do not see the value of projects like community gardens in rural areas. Instead of considering the multiple possible social and environmental benefits (Levkoe, 2006; Santo, Palmer, \& Brent, 2016; Urban Agriculture Working Group, 2013; Winne, 2008), some municipal staff have stated that they see these projects' food-producing roles as redundant in areas where agriculture is so close by (Martin, Drummond, \& Znajda, 2016). Considering the social reproductive identity of urban agriculture could raise questions about the prioritization of production through food-growing operations that are large, for-profit, only sometimes produce for local consumption and, as described earlier, traditionally seen as a masculine endeavour. Expanding the definition of urban agriculture is necessary for raising the visibility, validation, and ultimately the support of projects outside urban areas, such as those in Durham's hamlets and villages.

A problem with narrower municipal definitions of urban agriculture is that they can impede policy support of, for example, emergent rooftop gardens or projects in small towns. Supportive policies can attest to the value of projects and help to make their work possible and fruitful while restrictive policies may challenge the feasibility of some of these projects. Likewise, the absence of relevant policies, such as those around edible front yard gardens, greenhouses, rooftop gardens, and urban farms, can leave community groups uncertain of their rights and leave their work unvalidated and decisions about it subject to municipal staff discretion (Martin, 2016). Importantly, the usage of an intersectional lens may reveal the differential effects that such policy contexts can have on people and projects. For instance, insurance requirements and sale prohibitions can compromise projects that already have few financial resources, while zoning by-laws can disproportionately affect food generation and community-building in lower income, marginalized, or isolated communities that need them. Notably, DIG has advocated for local small entrepreneurs who are prevented from growing microgreens in warehouses on industrial land not zoned for food growing. Using feminist 
intersectional and social reproduction lenses to consider the issue of identity in the work of DIG reveals that many of the barriers it faces derive from an overly simplified rural/urban binary.

\section{Knowledge}

Applying both an intersectional and ethics of care lens to DIG's deployment of knowledge reveals the extent to which DIG is nurturing marginalized knowledges. Within DIG, as with many urban agriculture groups, knowledge is developed on the ground (often literally) as people work together to determine the best paths to address their communities' own food-related health, social, and environmental priorities. Through experience, members develop understandings, not only of food production, but also of project-building and the specific needs and strengths of their communities. DIG encourages this process by providing support and guidance as needed while respecting each group's need to guide itself and make its own decisions and mistakes along the way. Furthermore, the organization acts as an intermediary by exploring, gathering, and synthesizing projects' concerns and transmitting them to municipal governments and conversely, sharing municipal policy with DIG members.

Nonetheless, DIG has struggled to have the community-based expertise of urban agriculture recognized and valued. In general, the organization has found that local governments have overlooked knowledge developed at the community level by, for example, favouring the presumed expertise of municipal staff or inviting only authorities from areas outside the region such as Toronto to events to share knowledge about urban agriculture. However, knowledge from the ground is crucial for interrupting a cycle whereby that which is not imaginable, understood, or valued by policy makers is not protected in policy, and that which is not supported in policy remains difficult to realize on the ground.

The legitimacy and value of diverse origins of knowledge, especially those rooted in lived experience, have a long history of attention in feminist theory. Not only have feminists challenged assumptions of knowledge as singular, discoverable, and disembodied, they have also contextualized knowledge and reassigned expert status to those who live closest to the effects of uneven relationships (Haraway, 1988; Hill Collins, 2009; Scott, 1991; Smith, 1999).

An intersectional lens can bring to light multiple legitimate knowledge sources by prompting questions about whose knowledge matters. By interrogating bases of assumed knowledge such as formal education, experience, geographical positioning, financial resources, and political capital, an intersectional lens may point to exclusions of knowledge types and knowledge holders. At the same time, it could bring into focus the similarities between urban agricultural and political actors- and in doing so might illuminate knowledge sources, such as traditional Indigenous, low-income, or newcomer voices, that may be underrepresented in both groups. As Allen (2010) argues, local food initiatives can interrupt inequalities and exclusions but, without critical analysis, they can also reproduce them. For instance, recognizing its need for 
greater understanding of Indigenous food production, in recent years DIG has organized trips to learn about Anishinaabeg relationship with wild rice.

In some ways DIG is shaping its knowledge to be recognizable to the "main business" (Smith, 1999, p. 37). The president of DIG's board of directors is clear on wanting DIG's work to be taken seriously, as she shows in discussing a draft of promotional materials for the organization:

\begin{abstract}
We are not a network of gardens, we are a collaboration of urban ag and food related projects. [...] References to gardens will not help us get funding for the kinds of things we want to do - like support trips to educate, develop new experts through Table Talks, fund new garden start up and renewal projects at established gardens, mentor, develop materials and offer workshops, find funding for commercial urban ag projects, advocate with municipalities, partner with municipalities, organizations, individuals and entrepreneurs, symposiums etc. I think it [the promotional material] might paint us a little too much as just nice people with gardens not people out to make a difference." (Mary Drummond, personal communication, July 9, 2018)
\end{abstract}

This quote shows a funding-driven translation that, while highlighting DIG's educational and advocacy roles, also shifts focus from "being" to "doing" by downplaying the relationshipfocus of "nice people" and instead highlighting actions that "develop," "fund," "advocate," and "partner." DIG is practicing such translation by introducing an annual member project survey to collect metrics around project members, food production, and distribution to various organizations. By starting to quantify the impacts of local projects, DIG is attempting to make the effects of urban agriculture intelligible to funders and policy makers. In addition, DIG's ${ }^{3}$ urban agriculture policy scan research provided the organization with opportunities to collaborate with municipal staff but it also largely omitted the relational benefits that occur within urban agriculture projects.

\title{
Work
}

The use of social reproductive and intersectional lenses to consider the work of urban agriculture can reveal distinct parallels with the ways in which domestic labour is performed and the extent to which it is supported in society. DIG's substantially unpaid labour is a valuable and constrained resource that makes possible almost all of what the organization does. Nearly all of the work that occurs at the board, project coordination, and project participation levels is unpaid. On the one hand, the choice to avoid hiring staff has allowed DIG to operate on a smaller budget and to avoid investing much time and effort into grant proposals or employment-related

\footnotetext{
${ }^{3}$ This research occurred in partnership with the Durham Food Policy Council and Nourishing Communities.
} 
administration. This choice may also contribute to a more intentional workforce where workers participate for reasons other than income. However, recognizing the need for projects to have the resources to sustain themselves and members to have compensation and validation for the work they do, DIG is looking at ways that projects and their members can earn money from the food that they produce or process. To that end, it has advocated for greater flexibility in home production regulations so that growers may process and sell their own food.

The actual option for individuals to engage in unpaid labour in the community can, in fact, be both constrained by and produced through one's own or one's family members' paid work. For example, participating in a garden project for no pay requires time free from other obligations and made available through income from elsewhere. As an example, DIG's president traces her own allocation of substantial volunteer time back to the opportunity provided through the income from her partner's full-time job. Conversely, individuals' own employment, like her part-time employment since her partner's retirement, can leave them with less time to devote to such endeavours.

DIG's work to nourish individuals, families, communities, and eco-systems constitutes a form of social reproduction. It provides ways of meeting nutritional, relational, physical, and educational needs while, in some ways, upholding the dominant political-economic apparatus. ${ }^{4}$ The organization's patchwork of unpaid labour, donations, memberships fees, grants, and fundraising evokes feminist political economy scholars' observation of women's social reproductive role as household "shock absorbers" (Bakan \& Stasiulis, 2005, p. 24) for resource shortages. That is, over time women have used resourceful, often informal, methods to ensure that household members' needs are met (Little, 1998; Luxton, 1980; Luxton \& Corman, 2001), a responsibility that has increased as neoliberal policies and logics have emerged (Bezanson, 2006; Neysmith et al., 2012). Projects like community gardens similarly make inventive use of available resources, in the attempt to provide participants and their households with some padding against household food insecurity and social exclusion.

Still, DIG member projects experience pressure from municipalities to expand the number of community garden plots, reduce garden waitlists, and contribute more produce to food banks. In a similar vein, feminist scholars have found women's unpaid caring labour to be treated within and outside the home as infinitely expandable (Bakan \& Stasiulis, 2005; Bezanson, 2006; Braedley, 2006; DeVault, 1991; Luxton \& Corman, 2001). Furthermore, the combination of limited organizational resources and boundless commitment by some in the organization can lead them to overextend themselves, similar to what is observed in the domestic realm where women "often fail to take care of their own nutritional needs" (Allen \& Sachs,

\footnotetext{
${ }^{4}$ In fact, McClintock (2018) sees urban agriculture work as a form of social reproduction performed primarily by women for household benefit. However, he contends that this labour generates "sustainability capital," the benefits of which are reaped by municipal governments, developers, businesses, and other organizations who each promote and profit from the comparative greenness of their communities, especially city centres. He also sees urban agriculture as contributing to an "ecogentrification" (p. 580) that draws more White and privileged residents.
} 
2007 , p. 10). For example, coordinators of community gardens, especially those gardens that are on municipal land or are the only ones in their communities, experience much pressure to create additional plots, which creates additional work. For the goals of organizations like DIG to be realized, their social reproduction must be supported. As Dowling (2016) asserts, "Having the means, time and capacity to engage in social reproduction is the key to the task of social and ecological transformation towards a socially and ecologically sustainable society" (p. 463).

Intersectional analysis may be a valuable tool here for exploring the social reproductive work of urban agriculture. The profile of any urban agriculture initiative reflects a blend of characteristics such as gender, age, ability, caregiving responsibilities, ethno-racial-cultural background, employment status, and income. It suggests, for example, who is available, who can afford to participate, who can participate unencumbered by other caring responsibilities or by unmet accessibility needs, who feels welcome, who cares to participate, and sometimes who is expected to devote more time and effort. Consideration of the intersections that affect participation may enrich understandings of urban agriculture by offsetting uncritical and ideological readings of participation or non-participation. That is, it can serve as a reminder that participating in urban agriculture activities may not be practical, feasible, or expected for everyone. In doing so, it may not only lead to recommendations for making urban agriculture projects more inclusive, but it may also help to guard against sweeping assertions about the potential of urban agriculture projects. Instead it may reveal the necessity for greater state- and other structurally-based interventions around issues such as food insecurity, biodiversity, and social inclusion.

\section{Relationship}

A final area that lends itself to a feminist analysis is DIG's focus on relationship. While urban agriculture constitutes a site of labour and social reproduction, it also reveals a collective ethic of care which focuses on interrelationships and interdependencies. Feminists have long argued for recognizing the significance of care. According to Duffy (2011), "We should be able to value relationship without reducing care to the warm and fuzzy" (p. 140). An ethics of care lens reveals both the existence and the power of relationship nurtured through urban agriculture.

Some of the well-documented value of urban agriculture projects in general includes community dimensions such as the promotion of social capital, community building, social inclusion, and civic engagement (Levkoe, 2006; McClintock, 2018; Santo, Palmer, \& Brent, 2016; Winne, 2008). Some authors even assert that community gardens centre more on growing community than growing food (Parry et al., 2005; Winne, 2008). Through its emphasis on care and relationship-building, urban agriculture may even have more in common with the home kitchen than with conventional agriculture. For example, community gardens have been found to take on many of the caring functions of the domestic space (Hondagneu-Sortelo, 2017; 
Schmelzkopf, 1995). In fact, Hondagneu-Sortelo (2017) contends that, for the Latino immigrants she studied in Los Angeles, community gardens formed versions of:

hybrid-domestic places where basic social reproductive activities of food production, meal preparation, and eating occur, where children are nurtured and protected, where the sick are healed and as sites providing inviting places for moments of leisure, socializing and for quiet individual reflection (p. 26).

Relationships develop throughout DIG in many ways. For instance, in community garden settings, they grow informally out of the exchange of knowledge, skills, seeds, and plants. DIG and its member projects also actively cultivate opportunities for relationships to develop across differences such as gender, age, culture, income, and ability, through means such as low or sliding membership fees, children's projects, free public workshops, and accessible garden plots and pathways. Some gardens even use benches, large shade trees and gardener gatherings to promote connection between people. Overall, across DIG's member projects, working together in the gardens helps people to develop "understanding, mutual aid, and friendship across difference" (Martin, 2016).

An ethics of care perspective serves as a reminder of the value of growing relationships and community, that which lies beyond Smith's (1999) "main business" (p.37) of capitalism. As Gibson-Graham (2006) similarly point out,

While some types of economic activity are seen as essential to social survival, and therefore necessitous of intervention, others are viewed as frosting on the social cake. Though it may be widely recognized and lamented that child-care and its low wage providers are in difficult economic straits, policymakers will remind us that unless we take care of manufacturing, we are all up the creek." (p. 107).

DIG also shows how urban agriculture's potential for community-building extends beyond its own circles in its own place and time. Care is shown through the provision of food for growers' families, local schools, food banks, community centres, churches, local businesses, and other groups. In addition, through activities such as awareness raising, orchard growing, pollinator support, and composting, the organization helps to provide for human and non-human entities today as well as into future seasons and generations. Overall, DIG reveals a focus on building relationships among individuals, communities, and nature.

There is more to this relationship building than what Duffy (2011) calls the "warm and fuzzy" (p. 140). DeVault (1991), in her research on domestic caring and food work, contends that care is undertaken partly an expression of love, identity, and creativity, partly as a (subservient) duty, and partly as a response to recognizing that this is what is needed to ensure the survival and cohesion of the group. DIG is particularly motivated by this third aspect. It operates on the conviction that addressing critical problems of survival like food insecurity and 
climate change requires "all hands on deck" working together-and that this collective action is facilitated through the meeting of both material and relational needs. This ethos is represented in DIG's vision, "Growing Food and Community" (DIG, 2019).

Using an ethics of care perspective for urban agriculture projects also exposes interdependencies that extend beyond the interpersonal. It reveals webs of dependence that tie gardens' success to the personalities of their membership as well as factors such as weather, pests, and regulations. As DIG's president points out, urban agriculture projects by their very nature help to level unequal playing fields since, for example, everyone in a garden is affected by rain, droughts, pests, or frost (Mary Drummond, personal communication, 2016). I would argue that the illumination of such interdependencies cultivates a key to addressing one of this generation's toughest problems: humility. Duffy states (2011), “At its most theoretical level, care has been presented as a practice or ethic that encompasses interdependence, nurturance, and relationship, in contrast to the dominant US values of competition, individualism, and rationality" (p. 12). In an era of hyper-individualism, intensified anthropocentrism, and adversarial politics, it may prove useful to build relationships, recognize interdependencies, and proceed with humility in approaching the daunting tasks of mending damages to environmental, political, and social systems.

\section{Discussion and conclusion}

Food production has a long history of being painted as a male endeavour regardless of women's significant efforts in it. As described earlier, a look into how women grow food has found them to focus more on developing community, engaging in small-scale production, caring for the land, and feeding those around them, all of which are consistent with practices and priorities of urban agriculture. Urban agriculture organizations like DIG form a part of 1) the social economy where their social and environmental goals surpass their economic ones, which overlaps with 2) the informal economy where much of what they do occurs outside of formal economic practices. Such goals and practices often bear a feminine coding that may leave these organizations undervalued, underfunded, and marginalized. However, little scholarly work addresses the feminization of urban agriculture organizations themselves in Canada and North America. I refer to feminization as 1) an association with traits that have been broadly seen as feminine or attributed to women and 2) social positioning that traditionally or enduringly affects women disproportionately.

This article reflects an attempt to address this gap in the literature. It considers the applicability of feminist theory tools such as intersectional, social reproduction, and ethics of care lenses for exploring urban agriculture organizations such as DIG. By venturing beyond an emphasis on gendered divisions of labour or philosophies among individuals in such initiatives, I have tried to shine more light on the social positioning and impact of these organizations 
themselves. Overall, a review of DIG-related materials demonstrates a certain feminization of the organization in the areas of identity, knowledge, work, and relationship.

First, DIG has needed to advocate for policy makers to more accurately consider the multi-faceted identity of urban agriculture in Durham Region. McKeen (2004) contends that political activity is about changing meaning since policy both provides language and creates actors. In this case, DIG is attempting to change meaning by helping to ensure that local policy language is informed by an understanding of the complexity and potential of local urban agriculture. The challenge of asserting identity bears a resemblance to the challenge of women and marginalized people to be recognized - and valued - in their complexity. In DIG's case, an intersectional analysis can challenge all involved to reconsider assumptions about who feeds whom, who produces food, and where they do so - because these considerations in turn determine the language that works to determine, through policy, who produces food and who benefits from it.

Second, the community-based knowledge of urban agriculture projects and their members may be overpowered by knowledge grounded in assumptions about, for example, progress and productivity. An intersectional lens can reveal multiple sources of valid knowledge and the power structures that allow some of them to be voiced above others. The feminizing inaudibility of women's voices and women's resulting need to translate into the language of louder voices can be seen in DIG's need to translate community-based knowledge for policy and funding audiences in order to be understood and valued.

Third, the work of DIG demonstrates a heavy reliance on unpaid labour, patterns of shock absorbing, and perceived expandability, all of which feminists identify in domestic social reproductive work. DIG's work can benefit from intersectional and social reproductive lenses which demand attention to who is doing and who is affected by the work to meet urban agriculture goals. Specifically, these lenses encourage the exploration of who does, who can, and who should take responsibility for sustaining individuals, communities, and ecosystems.

Finally, DIG's focus on care through relationship building and community building lends itself to an ethics of care perspective which raises questions about interrelatedness, interdependence, vulnerability, and humility- and the various webs of connection that urban agriculture helps to support. Far from a sentimental concept, care as perceived through an ethics of care lens views connection as essential for addressing today's most intractable dilemmas. Once again, feminization is visible with DIG through its provision of and reasons for providing care. DeVault (1991) explains this feminization by saying,

Through caring work, women have participated in the activities that structure their subordination in society. They have participated not only because of social coercion, but also because of deeply-held beliefs about connection and people's responsibilities to one another, and commitments to fostering growth and relationship (p. 2). 
In the end, this article suggests that feminist theoretical tools may provide useful resources for illuminating and revaluating the impacts of urban agriculture organizations. However, it represents an exploration of just one set of feminist theoretical tools as they pertain to the themes of one organization. Understandings of urban agriculture could benefit from a deeper dive into feminist theory, its approaches, history, and debates, and how they apply to a range of urban agriculture organizations. In doing so, it will be important to go beyond feminization to consider how urban agriculture and food production are also racialized, classed, and colonized.

It is not DIG's association with feminine coding - through complex identities, knowledge from the ground, social reproduction, and relationship - that is problematic. Instead it is the way in which these matters are all feminized in their social positioning. That is, they are all lamentably undervalued and marginalized. If organizations like DIG are to help build healthier, more resilient communities through stronger, more sustainable food systems, these matters will need shift into the "main business" of our economic, social, and political systems. Through awareness building, reframing, and advocacy, urban agriculture organization like DIG work to prompt this shift.

Acknowledgements: Special thanks for the helpful guidance from my anonymous reviewers, the board members of DIG, Stephanie Dotto, and the special edition editorial team.

\section{References}

Acker, J. (2006). Class questions, feminist answers. Lanham, Maryland: Rowan \& Littlefield Publishers Inc.

Allen, P. (2010). Realizing justice in local food systems. Cambridge Journal of Regions, Economy, and Society, 3(2), 295-308.

Allen, P., \& Sachs, C. (2007). Women and food chains: The gendered politics of food. International Journal of Sociology of Food and Agriculture, 15(1), 1-23.

Bakan, A., \& Stasiulis, D. (2005). Negotiating citizenship: Migrant women in Canada and the global system. Toronto: University of Toronto Press.

Beagan, B., Chapman, G., D’Sylva, A., \& Bassett, B.R. (2008). 'It's just easier for me to do it': Rationalizing the family division of foodwork. Sociology, 42(4), 653-671.

Bezanson, K. (2006). Gender, the state, and social reproduction: Household insecurity in neoliberal times. Toronto: University of Toronto Press.

Brady, J., Gingras, J., \& Power, E. (2012). Still hungry: A feminist perspective on food, foodwork, the body and food studies. In M. Koc, J. Sumner \& A. Winson (Eds.), Critical perspectives in food studies (pp. 122-135). Don Mills, Ontario: Oxford University Press. 
Brady, J., Parker, B., Belyea, S., \& Power, E. (2018). Filling our plate: A spotlight on feminist food studies. Canadian Food Studies, 5(1), 1-7.

Braedley, S. (2006). Someone to watch over you: Gender, class, and social reproduction. In K. Bezanson \& M. Luxton (Eds.), Social reproduction: Feminist political economy challenges neo-liberalism (pp. 215-230). Montreal: McGill-Queen’s University Press.

Brandth, B., \& Haugen, M.S. (2010). Doing farm tourism: The intertwining practices of gender and work. Signs: Journal of Women in Culture and Society, 35(2), 426-446.

Brodhagen, A. (2014). Farmers feed cities campaign has been retired. Retrieved from: https://www.farms.com/ag-industry-news/farmers-feed-cities-campaign-has-been-retired316.aspx

Buckingham, S. (2005). Women (re)construct the plot: The regen(d)eration of urban food growing. Area, 37(2), 171-179.

Chiappe, M.B., \& Butler Flora, C. (1998). Gendered elements of the alternative agriculture paradigm. Rural Sociology 63(3), 372-393.

Cho, S., Crenshaw, K. W., \& McCall, L. (2013). Toward a field of intersectionality studies: Theory, applications, and praxis. Signs, 38(4), 785-810.

Collins, P., \& Bilge, S. (2016). Intersectionality. Cambridge: Polity Press.

DeLind, L.B., \& Ferguson, A.E. (1999). Is this a women's movement? Human Organization. 58(2), 190-200.

DeVault, M.L. (1991). Feeding the family: The social organization of caring as gendered work. Chicago: University of Chicago Press.

DIG. (n.d.). What we do. Retrieved from: http://www.durhamdigs.ca/what-we-do/.

DIG (2019)._DIG: Durham Integrated Growers for a Sustainable Community [Brochure].

Dowling, E. (2016). Valorised but not valued? Affective remuneration, social reproduction and feminist politics beyond the recovery. British Politics, 11(4). pp. 452-468.

Duffy, M. (2011). Making care count: A century of gender, race, and paid care work. Piscataway, New Jersey: Rutgers University Press.

Fox, B. (2009). When couples become parents: The creation of gender in the transition to parenthood. Toronto: University of Toronto Press.

Gibson-Graham, J. K. (2006). The end of capitalism (as we knew it): A feminist critique of political economy. Minneapolis: University of Minnesota Press.

Haraway, D. (1988). Situated knowledges: The science question in feminism and the privilege of partial perspective. Feminist Studies, 14(3), 575-599.

Hesse-Biber, S., \& Leckenby, D. (2004). How feminists practice social research. In S.N. HesseBiber and M.L. Yaiser (Eds.) Feminist perspectives on social research (pp. 209-226). New York: Oxford University Press.

Hill Collins, P. (2009). Black feminist thought: Knowledge, consciousness, and the politics of empowerment. New York: Routledge. 
Hondagneu-Sortelo, P. (2017). At home in inner-city immigrant community gardens. Journal of Housing and the Built Environment, 32, 13-28.

Levkoe, C. (2006). Learning democracy through food justice movements. Agriculture and Human Values, 23(1), 89-98.

Little, M. (1998). No car, no radio, no liquor permit: The moral regulation of single mothers in Ontario, 1920-1997. Toronto: Oxford University Press.

Luxton, M. (1980). More than a labour of love: Three generations of women's work in the home. Toronto: Women's Educational Press.

Luxton, M. (2006). Feminist political economy in Canada and the politics of social reproduction. In K. Bezanson \& M. Luxton (Eds.) Social reproduction: Feminist political economy challenges neo-liberalism (pp. 11-44). Montreal: McGill-Queen's University Press.

Luxton, M., \& Corman, J. (2001). Getting by in hard times: Gendered labour at home and on the job. Toronto: University of Toronto Press.

Martin, M.A. (2016). DIG (Durham Integrated Growers for a Sustainable Community): A Case Study. Centre for Sustainable Food Systems, Wilfrid Laurier University.

McClintock, N. (2018). Cultivating (a) sustainability capital: Urban agriculture, ecogentrification, and the uneven valorization of social reproduction, Annals of the American Association of Geographers, 108(2), 579-590.

McKeen, W. (2004). Money in their own name: The feminist voice in poverty debate in Canada, 1970-1995. Toronto: University of Toronto Press Incorporated

McMurtry, J.J. (2004). Social economy as political practice. International Journal of Social Economics, 31(9/10), 868-878.

Miller, T. (2011). Making sense of fatherhood: Gender, caring and work. Cambridge: Cambridge University Press.

Moyles, T. (2018). Women who dig: Farming, feminism, and the fight to feed the world. Regina: University of Regina Press.

Neysmith, S., Reitsma-Street, M., Baker-Collins, S., \& Porter, E. (2012). Beyond caring labour to provisioning work. Toronto: University of Toronto Press.

Nourishing Communities. (n.d.). The social economy of food. Retrieved from: http://nourishingontario.ca/the-social-economy-of-food/.

Parry, D.C., Glover, T.D., \& Shinew, K.J. (2005). 'Mary, Mary quite contrary, how does your garden grow?': Examining gender roles and relations in community gardens, Leisure Studies, 24(2), 177-192.

Patil, V. (2013). From patriarchy to intersectionality: A transnational assessment of how far we've really come. Signs, 38(4), 785.

RUAF Foundation. (2019). Urban agriculture: what and why? Retrieved from: https://www.ruaf.org/urban-agriculture-what-and-why 
Sachs, C., \& Patel-Campillo, A. (2014). Feminist food justice: Crafting a new vision, Feminist Studies, 40(2), 396-410.

Santo, R., Palmer, A., \& Brent, K. (2016). Vacant lots to vibrant plots: A review of the benefits and limitations of urban agriculture. Retrieved from Johns Hopkins Centre for a Livable Future website: http://www.jhsph.edu/research/centers-and-institutes/johns-hopkinscenter-for-a-livable-future/_pdf/research/clf_reports/urban-ag-literature-review.pdf.

Schmelzkopf, K. (1995). Urban community gardens as contested space, Geographical Review, 85(3), 364-381.

Scott, J. (1991). The evidence of experience, Critical Inquiry, 17(4), 773-797.

Smith, D. E. (1999). Writing the social: Critique, theory, and investigations. Toronto: University of Toronto Press.

Statistics Canada (2017). 2016 Census of Agriculture. Retrieved from: https://www150.statcan.gc.ca/n1/daily-quotidien/170510/dq170510a-eng.htm?HPA=1.

Sumner, J., Mair, H., \& Nelson, E. (2010) Putting the culture back into agriculture: civic engagement, community and the celebration of local food, International Journal of Agricultural Sustainability, 8(1-2), 54-61.

Swanson, L.J. (2015). A feminist ethic that binds us to Mother Earth. Ethics \& the Environment, 20(2), 83-103. Indiana University Press.

Tronto, J. (2013). Caring Democracy: Markets, equality and justice. New York: New York University Press.

Urban Agriculture Working Group. (2013). Urban agriculture policy, planning and practice: A report for the City of Hamilton, Ontario. Commissioned by the Neighbourhood Development Strategy Office. Retrieved from: https://www.hamilton.ca/sites/default/files/media/browser/2015-0306/urbanagriculturepolicyplanningandpractice.pdf.

Vosko, L. F. (2000). Temporary work: The gendered rise of a precarious employment relationship. Toronto: University of Toronto Press

Winne, M. (2008). Closing the food gap: Resetting the table in the land of plenty. Boston: Beacon Press.

Yuval-Davis, N. (2006). Intersectionality and feminist politics. The European Journal of Women's Studies, 13(3), 193-209. 